\title{
СЕКСУАЛЬНОЕ НАСИЛИЕ НАД ДЕТЬМИ: ИСТОРИЧЕСКИЕ АСПЕКТЫ, ПРАВОВЫЕ И ВРЕД ДЛЯ РАЗВИТИЯ РЕБЕНКА
}

\section{ОБЗОРНАЯ СТАТЬЯ}

GONÇALVES, Natamy de Almeida ${ }^{1}$, DIAS, Camila Santos²

GONÇALVES, Natamy de Almeida. DIAS, Camila Santos. Сексуальное насилие над детьми: исторические аспекты, правовые и вред для развития ребенка. Revista Científica Multidisciplinar Núcleo do Conhecimento. Год 06, эд. 09, Vol. 01, с. 183-208. Сентябрь 2021 года. ISSN: 2448-0959, Ссылка доступа: https://www.nucleodoconhecimento.com.br/психология/исторические-аспекты

\section{СВОДКА}

Поскольку это насилие, которое поражает нескольких детей и подростков в мире на протяжении всей истории, сексуальное насилие над детьми требует пристального внимания, учитывая, что это сложное явление и, во многих случаях, трудно идентифицировать, поскольку насильник обычно является доверенным лицом семьи и который должен заботиться о жертве, как биологические родители, отчимы, дяди или близкие друзья, например. Кроме того, большинство случаев сексуального надругательства происходит в собственном доме жертвы, где мало что ожидается от ребенка и подростка в уязвимом положении. Основываясь на описанных фракторах, это исследование представляет следующий вопрос: что такое сексуальное насилие и каковы его последствия для развития ребенка? Целью данной статьи было рассмотрение исторических и правовых аспектов сексуального насилия, изучение сложностей

\footnotetext{
${ }^{1}$ Аспирант по нейропсихологии факультета технологий, наук и образования - FATECE, аспирант по организационной психологии и психологии труда в Фонд Hermínio Ometto и окончил факультет психологии того же учебного заведения.

${ }^{2}$ Консультантом. Магистр психологии как науки и профессии (PUCCamp), специалист в области образования и психопедагогики (PUCCamp), специалист по нейропсихологии (Израильский госпитальный институт Альберта Эйнштейна), окончил факультет психологии (Фонд Hermínio Ometto - FHO).
}

RC: 98980

Доступно в: https://www.nucleodoconhecimento.com.br/психология/исторические- 
его определений и представление возможных последствий для жертвы. Для этого был сделан библиографический обзор качественного, описательного и исследовательского характера, поднимающий размышления по теме. Было замечено, что ребенок и подросток не всегда имеют юридическую поддержку, потерпев несколько раз насилия без надлежащего наказания своих агрессоров. Со временем принимаются законы, и в Бразилия Статут о детях и подростках (ECA) ознаменовал собой время определения прав детей и подростков, создания механизмов защиты, в том числе от насилия, такого как сексуальные надругательства. Наконец, в этом исследовании было рассмотрено, что существует недостаток информации для населения по этому вопросу, что подтверждает воспроизведение вышеупомянутого правонарушения. Было отмечено, что с учетом ущерба, нанесенного биопсихосоциальному здоровью жертвы и его/ее семьи, были проведены исследования и профилактические проекты, а также введены различные формы сообщения об этом преступлении. Был сделан вывод о необходимости разработки стратегий подготовки семей, специалистов и учреждений, отвечающих за гарантирование прав детей и подростков, с тем чтобы они могли вносить вклад в усиление борьбы с сексуальными надругательствами.

Ключевые слова: сексуальное насилие, сексуальное насилие над детьми, ребенок и подросток.

\section{1. ВВЕДЕНИЕ}

Когда речь заходит о предмете, присутствующего в различных частях мира и в различные исторические периоды, сексуальное насилие остается и сегодня и является важной темой, подлежащей рассмотрению, поскольку такое насилие постоянно воспроизводится. Waiselfisz (2012) показывает, что, согласно записям Инфрормационной системы по заболеваниям, подлежащим информированию (SINAN), в 2011 году в Бразилия прошли лечение 10425 детей, ставших жертвами сексуального насилия. В 2018 году в Бразилия было

RC: 98980

Доступно в: https://www.nucleodoconhecimento.com.br/психология/исторические- 
зарегистрировано не менее 32000 случаев сексуального насилия в отношении детей и подростков в 2018 году, что является самым высоким показателем уведомлений, когда-либо зарегистрированных Министерством здравоохранения. С 2011 года агенты здравоохранения обязаны рассчитывать уход. С тех пор цифры растут из года в год и составляют в общей сложности 177300 уведомлений по всей стране[3]. Однако, как отмечено Aded et al. (2006), считается, что выявленные или сообщенные случаи не говорят о реальности числа случаев. Одна из причин заключается в том, что в большинстве случаев агрессор находится очень близко или является частью семьи жертвы; другим фрактором является отсутствие идентификации случаев или даже убеждение, что нет никакого способа доказать акт злоупотребления, понимая в качестве конкретных доказательств только медицинское освидетельствование. Таким образом, считается, что число заболев значительно выше, чем предполагалось.

Основываясь на описанных фракторах, это исследование представляет следующий вопрос: что такое сексуальное насилие и каковы его последствия для развития ребенка? Целью данной статьи было рассмотрение исторических и правовых аспектов сексуального насилия, изучение сложностей его определений и представление возможных последствий для жертвы.

Это библиографический обзор качественного, описательного и исследовательского характера, для которого в качестве источника данных использовались книги, помимо научных статей, которые были найдены на поисковом сайте Google. Некоторые сайты, которые представляют важные данные по этому вопросу, также использовались в этом исследовании.

Учитывая, что сексуальное надругательство является насилием, которое происходит таким образом, что обычно препятствует его выявлению, а также вызывает у многих сомнения в том, как с ним бороться, необходимо провести дополнительные исследования, с тем чтобы все больше и больше знаний о

RC: 98980

Доступно в: https://www.nucleodoconhecimento.com.br/психология/историческиеаспекты 
механизмах, связанных с этим преступлением, и, таким образом, было разработано больше стратегий борьбы. Таким образом, данное исследование показывает свою социальную и научную значимость, способствуя прояснению предмета и другим исследованиям, которые будут проводиться из него.

\title{
2. СЕКСУАЛЬНОЕ НАСИЛИЕ: ОПРЕДЕЛЕНИЯ, ИСТОРИИ,
}

\section{ЗАКОНЫ}

Сексуальное насилие является социальным явлением, которое нуждается в особом внимании, поскольку это сложный вопрос, который связан с различными проблемами и порождает страдания для многих детей, подростков и семей, что является одним из нескольких видов насилия. Рассматривая различные определения сексуального надругательства, можно выделить определение, данное Министерством здравоохранения (BRASIL, 2002, стр. 13):

\begin{abstract}
Abuso sexual - consiste em todo ato ou jogo sexual, relação heterossexual ou homossexual cujo agressor está em estágio de desenvolvimento psicossexual mais adiantado que a criança ou o adolescente. Tem por intenção estimulá-la sexualmente ou utilizá-la para obter satisfação sexual. Apresenta-se sobre a forma de práticas eróticas e sexuais impostas à criança ou ao adolescente pela violência física, ameaças ou indução de sua vontade. Esse fenômeno violento pode variar desde atos em que não se produz o contato sexual (voyerismo, exibicionismo, produção de fotos), até diferentes tipos de ações que incluem contato sexual sem ou com penetração. Engloba ainda a situação de exploração sexual visando lucros como é o caso da prostituição e da pornografia.
\end{abstract}

Таким образом, будучи рассматриваемым как акт насилия, сексуальное насилие может быть совершено несколькими способами, от тех, при которых отсутствует ффизический контакт агрессора с ребенком или подростком, таких как вуайеризм, при котором наблюдение за наготой жертвы происходит для получения сексуального удовлетворения, и эксгибиционизм, при котором агрессор демонстрирует свои собственные половые органы. Это также может произойти путем демонстрации жертве порнографических видео и журналов,

RC: 98980

Доступно в: https://www.nucleodoconhecimento.com.br/психология/исторические- 
возбуждая их сексуальность ранним и искаженным образом; дарение денег, конфет или подарков ребенку или подростку, чтобы позволить агрессору надругаться над своим телом; изнасилование ее при оральном сексе, который также является средством передачи заболеваний, передающихся половым путем (ЗППП); или даже поддержание как вагинального, так и аннаального полового акта. Это может произойти даже без вектега жертвы или до причинения фризической травмы и психологического заболевания. Кроме того, такое насилие совершается не только взрослыми мужчинами в отношении детей: оно может совершаться подростками, женщинами, пожилыми людьми и разными людьми в разных обстоятельствах. Такое изменение способов сексуального надругательства может привести к трудностям в выявлении некоторых типов которые часто не признаются взрослыми в качестве таковых (BRASIL, 2002).

Кроме того, как подчеркивает министерство здравоохранения (BRASIL, 2002), сексуальное насилие охватывает сексуальную эксплуатацию, которая включает в себя, когда речь идет о деньгах, подарках или чем-то подобном, в коммерциализации тела ребенка и/или подростка, как в упомянутых примерах, которыми являются проституция и порнография. Однако, как отмечают Vega и Paludo (2015, стр. 48), «определение сексуальной эксплуатации было трудной задачей, в том числе для академической области». Faleiros и Campos (2000) в анализе лексики темы выявили терминологическую неточность. Авторы приводят пример: сексуальное насилие было установлено как сексуальное преступление, сексуальная виктимизация, сексуальное насилие, сексуальное насилие, сексуальное насилие, сексуальная эксплуатация, сексуальное насилие, сексуальное насилие, сексуальное возмущение и сексуальные травмы. Для того чтобы назвать насилие внутрисемейства, были найдены следующие термины: инцест, кровосмесительное сексуальное насилие, сексуальное насилие в семье, сексуальное насилие в семье.

RC: 98980

Доступно в: https://www.nucleodoconhecimento.com.br/психология/историческиеаспекты 
O uso sexual de menores de idade com fins lucrativos é designado ora como prostituição infanto-juvenil, ora como abuso sexual, ora como exploração sexual comercial. Por outro lado, um mesmo termo pode designar distintas realidades, como, por exemplo, o termo exploração sexual é utilizado pela OMS para designar situações de abuso sexual intra e extrafamiliar e prostituição, enquanto muitos autores o utilizam referindo-se apenas à exploração sexual comercial (FALEIROS; CAMPOS, 2000, p.4).

Таким образом, существуют также расхождения между авторами в отношении соответствующего словарного запаса для каждой ситуации. Тем не менее, для Faleiros и Campos (2000) использование разных терминов в качестве синонимов и как бы они были эквивалентны одному и тому же понятию, это не только терминология, но и вопрос эпистемологического охвата, то есть обличает отсутствие концептуализации проблемы. Эта теоретическая и концептуальная неопределенность обусловлена сложностью и разнообразием, а также тем фрактом, что отмена, осознание и решение этой проблемы все еще недавние, а также озабоченность детством, как будет показано ниже.

В дополнение к тому, что сексуальное насилие над детьми происходит поразному, сексуальное насилие над детьми происходит из разных мест на планете и описывается с древности, как показано Aded et al. (2006). Однако прогресс в предотвращении и смягчении последствий был незначительным. Что может затруднить решение этой проблемы, так это то, что она проходит через культурные, религиозные, юридические и профессиональные сложности со всего мира.

Oliveira (2006) отмечает, что на протяжении всей истории одной из характеристик, характерных для человеческой культуры, была небрежность по отношению к детям и подросткам, поскольку не было представления о слабости как характеристике детства, и этот вопрос мало обсуждался, так же как не было никакой политики защиты.

RC: 98980

Доступно в: https://www.nucleodoconhecimento.com.br/психология/исторические- 
Автор приводит несколько моментов истории, иллюстрирующих это пренебрежение, обозначая, что у многих народов древности сексуальное насилие над детьми считалось нормальным и, более того, многие из этих народов не делали различий между ребенком и взрослым, как в Спарте, например. В нем также говорится, что на Западе, в средние века, это различие также не проводилось, и ребенок подвергался различным видам наказаний; «[...] Как только она оказалась без необходимости в базовом материнском уходе, она стала взрослой и, таким образом, выросла» (OLIVEIRA, 2006, стр. 11). Таким образом, очень маленький ребенок не рассматривался как человеческое существо, а уровень смертности был высоким, что понималось как обычное явление.

Azambuja (2006, стр.3) представляет, что только в конце 17-го века ребенок начал иметь отличие от взрослого человека. До этого времени школы не были организованы по возрасту, их посещали дети и взрослые в одном и том же месте. По автору, «[...] с появлением понимания того, что детство является отдельным этапом взрослой жизни, наказание, фризическое наказание, избиение кнутами, палками и утюгами используются в качестве инструментов, необходимых для воспитания» (AZAMBUJA, 2006, стр.3). В 1780 году в Англии родители могли приговаривать детей к повешениям, по более чем двум сотням преступных типов. В Нью-Йорк в 1871 году девочка подверглась серьезному жестокому обращению и, поскольку для такой жалобы не было места, дело девочки Мэри Эллен в конечном итоге было передано в Общество по предотвращению жестокого обращения с животными, чтобы его можно было расследовать судом. Дело, вызвавшее большое возмущение населения, стало тем, что спроволло создание общества, ориентированного на защиту ребенка.

Согласно Azambuja (2006), что касается Бразилия, то первые суда, спущенные в море Португалией, состояли из мужчин и детей, осиротевших от короля, которые оказывали услуги во время поездки и подвергались сексуальному

RC: 98980

Доступно в: https://www.nucleodoconhecimento.com.br/психология/историческиеаспекты 
насилию со стороны моряков. Она говорит, что если случались штормы, то дети были первыми «грузами», которые были выброшены за борт.

Guerra et al. (2013) отмечает, что до начала 20-го века государство не занималось разработкой социальной политики, направленной на детей и подростков. Таким образом, католическая церковь была тем, кто разработал важные действия по уходу за детьми и подростками, называемыми «брошенными». Святые Дома Милосердия заботились не только о больных и больных, но и о детях, права которых были нарушены. Таким образом, в попытке уменьшить количество детей, зачатых вне брака и брошенных даже на улицах, из-за социального давления того времени, католическая церковь создала Колесо Разоблаченных. Это было цилиндрическое устройство, в которое помещали и оставляли ребенка, чтобы обеспечить анонимность тех, кто совершил оставление.

В конце Первой мировой войны недавно созданные международные организации начали формулировать кодексы прав человека. Новые органы начали уделять особое внимание правам ребенка. Вновь созданное Международное агентство труда (ныне Организация) вернуло свои конвенции, гарантирующие права работающих детей, а также в 1919 году на Конвенцию о ночном труде подростков (промышленность); также в 1921 году была разработана Конвенция о минимальном возрасте (сельское хозяйство). Однако большинство законодательных актов, разработанных в период между двумя мировыми войнами, не объясняют специфику права детей и подростков в отличие от прямых прав взрослых (UNICEF, 2009).

Первое определение фрормальных прав ребенка, которое было разработано молодыми международными организациями, возникло из работы Эглантин Джебб, которая основала в Англии в 1919 году организацию Save the Children и основала ее в Женеве в следующем году. , Международный союз Save the Children, для сбора средств на оказание экстренной помощи детям, 
пострадавшим в результате Первой мировой войны. Джебб в 1923 году заявил о своей позиции в отношении прав ребенка: «[...] Я считаю, что мы должны требовать определенных прав для ребенка и работать над тем, чтобы они были признаны на международном уровне» (UNICEF, 2009, стр.4) . Так, Международный союз Save the Children разработал предварительное предложение декларации, которая требовала особых прав детского населения, и 26 сентября 1924 года Лига Наций приняла ее в Женевской декларации прав ребенка. .

Так, в Женевской декларации обсуждаются пять основных принципов: право на условия материального и духовного развития; право на приоритет в освобожденных в рискованных ситуациях; право на помощь в условиях голода, инвалидности, болезни, правонарушения или сиротства; право на профрессиональную подготовку, которая направляет ребенка к жизни в обществе; и право на защиту от эксплуатации (UNICEF, 2009 год).

По данным Детского фонда Организации Объединенных Наций (UNICEF, 2009 г.), Вторая мировая война способствовала созданию Организации Объединенных Наций $(\mathrm{OOH})$. В результате слияния Международной ассоциации защиты детей, созданной в Брюсселе, и Союз Save the Children Международный, в результате был создан Международный союз защиты детей (International Union for Child Welfare - IUCW), в результате чего Организация Объединенных Наций одобрила проект Женевская декларация.

Веб-сайт Portal Brasil[4] показывает, что в 1927 году в стране был обнародован первый Кодекс законов о несовершеннолетних. В то время громкие случаи, вызвавшие большое общественное значение, побудили тогдашнего президента Вашингтона Луиса определить, что 18 лет должны быть минимальным возрастом для правонарушителей в тюрьме. То, что случилось с 12-летним мальчиком Бернардино, было одним из таких случаев. В 1926 году мальчик, который был чистить обувь, разозлился на клиента из-за его отказа платить за

RC: 98980

Доступно в: https://www.nucleodoconhecimento.com.br/психология/историческиеаспекты 
услугу, предоставляемую на улицах Рио-де-Жанейро. Ребенок бросил бы краску в этого парня, поэтому она оказалась в тюрьме на четыре недели. Бернардино был изнасилован в камере 20 взрослыми, что вызвало возмущение со стороны врачей, когда мальчик отправился в Санта-Каса.

Таким образом, распространение дела вызвало сильную полемику, положив начало общественной дискуссии, которая дошла до колес Конгресса, а также дворца Катет, где находилось место федерального правительства. Поэтому президент выбрал 12 октября (День защиты детей) для подписания Кодекса несовершеннолетних, который стал первым в стране законодательством специально для детей и подростков. Статья этого кодекса запрещала Колесо Разоблаченных. «С кодом мать должна будет зарегистрировать ребенка и, таким образом, доставить его в детский дом» (BRASIL, s/d).

Веб-сайт Всеобщей декларации прав человека[5] (ВДПЧ) показывает, что 10 декабря 1948 года в Париже такая декларация была провозглашена Генеральной Ассамблеей наций посредством резолюции 217 A (III). Это документ, который ознаменовал историю прав человека. ВДПЧ была разработана различными представителями различных правовых и культурных кругов со всего мира и стала общей нормой, так что она охватывает все народы и нации. Это утверждение исходит из того, что человек имеет право на достойную жизнь: «В то время как признание достоинства, присущего всем членам человеческой семьи, и их равных и неотъемлемых прав является основой свободы, справедливости и мира во всем мире [...]» (ВДПЧ, 1948).

По этому случаю ООН была более привержена обсуждению принципов ВДПЧ, но сам IUCW отстаивал идею нового документа, который был бы специфическим для прав ребенка, обновляя предыдущее заявление и повторяя принцип, что ребенок должен получать то, что человечество может предложить лучше всего. Декларация прав ребенка не была принята ООН до 20 ноября 1959 года. Одобрение Генеральной Ассамблеей имеет важное значение,

RC: 98980

Доступно в: https://www.nucleodoconhecimento.com.br/психология/историческиеаспекты 
поскольку оно подчеркивает необходимость отдельного рассмотрения прав ребенка. В Декларации прав ребенка подчеркивается эмоциональное благополучие ребенка и гарантируется его право на приоритетное внимание при получении чрезвычайной защиты. «Несмотря на эти изменения, в документе 1959 года сохранен подход к поиску ухода, направленный на спасение, охрану и защиту ребенка, придавая мало значения увеличению их власти» (UNICEF, 2009, стр. 5).

Inoue и Ristum (2008) означают, что насилие было основной причиной смерти в основном в молодой и детской аудитории. В Соединенных Штатах только в 1960 году насилие в отношении детей рассматривалось как медико-социальная проблема. «[...] особенно педиатры начали заниматься темой, показывающей последствия жестокого обращения и расхождения между радиологическими данными о травмах и объяснениями агрессоров» (MINAYO, 2002, стр. 109). Хотя это движение внутри медицины вызывало критику и обвинения в «медикализации насилия», оно оказало большое влияние на теоретическое производство, запуская исследования, а также на движения в пользу защиты прав детей. Таким образом, в медицинской сфрере началось социальное отвращение к сексуальному насилию, которое приобрело последовательность также со стороны Соединенных Штатов, наряду с укреплением фреминистского движения 1970 года.

1973 год был отмечен событием, которое сделало 18 мая, важным днем в календаре Министерства здравоохранения, памятным по сей день. Дело в том, что в этот день девятилетняя Арасели Кабрера Креспо исчезла из школы, где она училась, больше не видясь живой. Веб-сайт Национального совета по здравоохранению объясняет, что «Арасели был избит, изнасилован, одурманен наркотиками и убит в оргии наркотиков и секса. Его тело, лицо были в основном изуродованы кислотой» (BRASIL, s/d). Через шесть дней после инцидента тело было найдено на пустыре недалеко от центра города Витория, Эспириту-Санту. Такое мученичество имело большое значение, поэтому эта дата считается и

RC: 98980

Доступно в: https://www.nucleodoconhecimento.com.br/психология/историческиеаспекты 
помнится как Национальный день борьбы с сексуальными надругательствами и эксплуатацией детей и подростков.

В период с 1960-х по 1970-е годы неправительственные организации (НПО) проводили мобилизацию в защиту прав детей и подростков, что привело к большим успехам; таким образом, эти организации настоятельно призвали Организацию Объединенных Наций провозгласить 1979 год Международным годом ребенка, с тем чтобы привлечь внимание к проблеме, связанной с детством. «После заключения этого соглашения правительство Польши представило в Комиссию ООН по правам человека предварительный текст Конвенции о правах ребенка» (UNICEF, 2009, стр. 5). Таким образом, было огостельство подано, что завершение подготовки этого документа потребует лучшей подготовки и большего времени. Таким образом, этот процесс длился десять лет, учитывая, что разработка договора, охватывающего несколько областей культурного и социального толкования, является работой, требующей осторожности.

Minayo (2002) говорит, что в 1980-х годах в области мирового общественного здравоохранения насилие представляет собой существенную проблему. Движение специализированной помощи и профилактики обусловлено признанием заболеваемости и смертности в результате насилия в качестве серьезной проблемы для здравоохранения в его социальных аспектах, а также цели первичной, вторичной и третичной помощи. Также в 1980 году в Бразилия начали думать о предложениях в темпе общественного движения, которое подтвердило Конституцию 1988 года. Только в этом году ребенок считается субъектом прав, благодаря Федеральной конституции, и будет иметь Конвенцию Организации Объединенных Наций, в новую эру защиты прав детей и подростков.

За три года до принятия этой конституции, 4 июля 1985 года, Региональный центр внимания к жестокому обращению с детьми (CRAMI) был основан

RC: 98980

Доступно в: https://www.nucleodoconhecimento.com.br/психология/историческиеаспекты 
группой, состоящей из различных профессионалов Папского католического университета Кампинаса (PUC-Campinas), c участием представителей различные слои общества, такие как Бразильская коллегия адвокатов (OAB) Кампинас, Суд по делам несовершеннолетних и другие. Согласно собственному веб-сайту CRAMI[6], «обеспокоенная обычными случаями, когда дети, приходящие в государственные учреждения, демонстрируют следы побоев, ожогов, ссадин, внутренних кровоизлияний, эта группа основала CRAMI». Многие из этих детей умерли, и опекуны объяснили это падением или отсутствием внимания со стороны ребенка. Со временем был создан протокол по делам о домашнем насилии. После завершения дела были собраны данные, и социальный работник приступил к оказанию помощи в домах потерпевших, стремясь установить контакт с реальной ситуацией и, в зависимости от серьезности дела, направить потерпевшего в Суд по делам детей.

Веб-сайт CRAMI также сообщает, что «работа, разработанная высококвалифицированными специалистами из CRAMI, стала эталоном и способствовала открытию других CRAMI в штате Сан-Паулу». По решению Единой системы социальной помощи (SUAS) в 2014 году CRAMI распространила свои услуги на всех людей в ситуациях уязвимости и социального риска, больше не ограничиваясь обслуживанием детей и подростков, ставших жертвами домашнего насилия. Это неправительственная некоммерческая организация, которой помогают психологи, социальные работники и социальные педагоги, которые, согласно веб-сайту, продолжают миссию «Построение лучшего будущего для детей, подростков и уязвимых жертв домашнее насилие».

20 ноября 1989 года Генеральная Ассамблея ВОЗ приняла Конвенцию о правах ребенка, вступив в силу 2 сентября 1990 года. Это наиболее всеобъемлющий из всех договоров по правам человека и правовых документов по защите прав ребенка. Хотя в международном правозащитном оборудовании содержатся положения, защищаемые правами ребенка, Конвенция является первой,

RC: 98980

Доступно в: https://www.nucleodoconhecimento.com.br/психология/историческиеаспекты 
которая охватывает и формулирует все соответствующие аспекты прав, важных для ребенка, а именно экономические, культурные, политические и социальные. Тем не менее, это было первое международное оборудование, которое прямо признало, что ребенок является социальным субъектом, обладающим своими собственными правами (UNICEF, 2009).

Согласно UNICEF (2009, стр. 2), «посредством положений договора государства-участники по закону обязаны соблюдать права всех детей». Конвенция предусматривает 54 статьи и основывается на четырех основных принципах: наилучшее защитное интересы ребенка; недискриминация; уважение мнения ребенка; и право на выживание и развитие. Широкая цель, которую он имеет, и важность, которую он придает представлению, которое благоприятствует ребенку, определяют непрекращающееся значение всех действий, направленных на удовлетворение прав ребенка. «Конвенция подтверждает и обогащает права человека существенным образом» (UNICEF, 2009, стр. 2). Он подтверждает их, непосредственно применяя к ребенку многие из основных принципов международных документов по правам человека, которые уже существовали, таких, как недискриминация и универсальность; укрепляет их путем создания и расширения устройств, включенных в другое правозащитное оборудование, уточняя обязанности государств-участников в отношении ребенка. Она объединяет права детей, которые не были широко включены. В нем подчеркивается, что ответственность за осуществление прав ребенка должна возлагаться на тех, кто имеет связанные с этим обязанности, таких, как семья и лица, ответственные за ребенка, а также государстваучастники.

Конвенция имеет значение, которое выходит за рамки еe правовых последствий. Этот инструмент также способствовал трансформации отношения к детству. В конце концов, Конвенция определила условия детства, установив минимальные стандарты ухода, лечения, выживания, защиты, участия и развития, которые являются правами всех лиц, возраст которых не достиг 18-

RC: 98980

Доступно в: https://www.nucleodoconhecimento.com.br/психология/историческиеаспекты 
летнего возраста. В его статьях подтверждается, что необходимо защищать детство как другой период взрослой жизни и устанавливать время, в течение которого ребенок растет, учится, играет и развивается, чтобы затем права ребенка были полностью реализованы (UNICEF, 2009).

Как показывает Lemos (2008), открывая новую перспективу прав и обязанностей, основанную на доктрине комплексной защиты, Статут о детях и подростках (ECA), был обнародован в 1990 году в качестве Федерального закона № 8.069/90, гарантирующего уважение детей и подростков как людей в особом развитии:

Art. $3^{\circ}$ A criança e o adolescente gozam de todos os direitos fundamentais inerentes à pessoa humana, sem prejuízo da proteção integral de que trata esta Lei, assegurando-se lhes, por lei ou por outros meios, todas as oportunidades e facilidades, a fim de Ihes facultar o desenvolvimento físico, mental, moral, espiritual e social, em condições de liberdade e de dignidade (BRASIL, 1990).

Этот закон устанавливает новую схему, устанавливающую различные виды практики в некоторых аспектах, предусмотренные в Кодексе законов о несовершеннолетних 1927 и 1979 годов. «Если в Кодексе законов о несовершеннолетних объект был самым маленьким; в Уставе о детях и подростках объектом является ребенок и подросток как субъекты прав» (LEMOS, 2008, с.98). Таким образом, открывается новая социальная идентичность, называемая детьми и подростками. Изменились не только практики, но и объект другой.

ECA выступает с предложением построить модель интегральной защиты детей и подростков, не только ограничивая внимание после нарушения прав, но и до того, как произойдет нарушение, как это предусмотрено в его ст.70: «Каждый обязан предотвращать угрозу или нарушение прав детей и подростков» (BRASIL, 1990). Этот федеральный закон обеспечивает, среди прочего, защиту ребенка от любых видов насилия, включая сексуальное насилие.

RC: 98980

Доступно в: https://www.nucleodoconhecimento.com.br/психология/историческиеаспекты 
Известно, что в большинстве случаев обидчик имеет близость к семье. Как показывают Santos, Costa и Granjeiro (2009), большинство случаев сексуального насилия происходит в семье и, во-первых, практикуется биологическими родителями жертв и, во-вторых, отчимами. Это пример внутрисемейного насилия, которое, согласно Araújo (2002), представляет собой насилие, которое происходит в семье, затрагивая людей, которые живут или не живут в одном и том же месте, но которое не ограничивается только семьей, но затрагивает субъектов общего ведения в одном домашнем пространстве, независимо от того, имеют ли они родственные связи или нет. Для этих случаев ЕСА имеет специфику и одна из них упоминается в ст. 101:

$\S 2$ Sem prejuízo da tomada de medidas emergenciais para proteção de vítimas de violência ou abuso sexual e das providências a que alude 0 art. 130 desta Lei, o afastamento da criança ou adolescente do convívio familiar é de competência exclusiva da autoridade judiciária e importará na deflagração, a pedido do Ministério Público ou de quem tenha legítimo interesse, de procedimento judicial contencioso, no qual se garanta aos pais ou ao responsável legal o exercício do contraditório e da ampla defesa (BRASIL, 1990).

Эти законы для защиты детей и подростков от сексуального насилия крайне необходимы, поскольку они касаются чего-то серьезного и могут причинить много вреда жертве, как будет указано ниже.

\section{1 УЩЕРБ ЖЕРТВЕ И ВОЗМОЖНЫЕ ДЕЙСТВИЯ}

Среди последствий, которые сексуальное насилие может причинить детям и подросткам, можно выделить: когнитивные, поведенческие, эмоциональные и социальные нарушения; социальная изоляция, преувеличенный страх, трудности в адаптации, мысли об убийстве и самоубийстве, языковой дефицит, потеря интереса к играм и учебе, побеги из дома, членовредительство, социальная изоляция, агрессивность и другие последствия, которые могут серьезно поставить под угрозу жизнь жертвы (SERAFIM et al., 2011).

RC: 98980

Доступно в: https://www.nucleodoconhecimento.com.br/психология/исторические- 
Prado и Carneiro (2005) обсуждают, с точки зрения психоанализа, о травме, которая, по их мнению, этот термин будет подчеркивать ущерб, создаваемый способностью символизировать и трансформироваться, а также подтверждение мертвых психических зон, которые будут мешать будущим поколениям, достигая их любовного выбора и их перспективы достижения своей сексуальности.Авторы обсуждают два вида травм, предлагая называть их активными и кумулятивными, причем первый остается в психике человека неоднократно, особенно когда речь идет о сексуальном насилии над ребенком, и может иметь различные проявления, такие как распущенность, выступления, психопатические состояния, депрессии, психосоматические состояния и т.д.

Кумулятивная травма относится к повторяющемуся напряжению невыполнения роли матери как защитного щита, которое уходит в фразу развития, в которой нуждается ребенок матери, выполняющей свою роль; эти материнские неудачи могут поддаться коррекции в соответствии с процессом созревания. Что касается активной травмы, то «так же, как и кумулятивная травма, она предательна, только вместо того, чтобы действовать и успокаиваться на протяжении всего детства и юности, она делает это на протяжении всей жизни и за ее пределами, поскольку она переиздается через поколения» (PRADO; CARNEIRO, 2005, с.31). Таким образом, травма может мешать и причинять страдания на протяжении всей жизни жертвы, принося несколько возможностей долгосрочных серьезных последствий.

Отношения ребенка с жестокими взрослыми, приводящие к разрушению доверия и неуверенности, благоприятствуют жертве не верить в надежность и безопасность людей в целом, что может отразиться на их будущих отношениях. Так, начиная с подросткового возраста, известны случаи, когда жертвы в отчаянии за любовь становятся беспорядочными; с другой стороны, другие редко делают себя доступными для отношений; оба случая переходят в сторону изоляции и депрессии (PRADO; CARNEIRO, 2005 ГОД).

RC: 98980

Доступно в: https://www.nucleodoconhecimento.com.br/психология/исторические- 
Padilha (2002) говорит об особенности сексуального насилия, указывая на то, что часто нет никаких фризических доказательств его завершения, а затем агрессор утверждает, что он не заставлял ребенка ничего делать. «Рассмотрение этой характеристики этого явления, по-видимому, имеет основополагающее значение при планировании мероприятий по профилактике или лечению ситуаций сексуального, внутрисемейного или внесемейного насилия» (PADILHA, 2002, стр. 210). Таким образом, предотвращение такого насилия требует знания движений, пронизывающих агрессию.

Как уже упоминалось, Министерство здравоохранения указывает, что сексуальное насилие «проявляется в форме эротических и сексуальных практик, навязываемых детям или подросткам посредством фризического насилия, угроз [...]», но добавляет: «[...] или побуждение к его будет » (BRASIL, 2002 , с.13). Таким образом, на самом деле большинство случаев сексуального насилия происходит под угрозой со стороны агрессора, в тени насилия, шантажа и т. Д., Однако побуждение жертвы к волеизъявлению также квалифицируется как агрессия.

В настоящее время все еще существует ошибочная концепция, которая считает, что если ребенок и особенно подросток потворствуют половому акту, ситуация не будет представлять собой злоупотребление. Однако бразильское законодательство не оставляет сомнений в том, что дети и подростки уязвимы, поскольку, как уже было доведено до этого исследования, если человек находится в стадии психосексуального развития раньше, чем жертва, это будет сексуальное насилие (BRASIL, 2002).

Поэтому, даже если ребенок или подросток соглашается на половой акт, это явно предосудительно бразильским законодательством. Что касаясь сексуальных преступлений против уязвимых, статья 217-А Уголовного кодекса ясно дает понять, что «иметь плотскую связь или практиковать другое

RC: 98980

Доступно в: https://www.nucleodoconhecimento.com.br/психология/историческиеаспекты 
либидинозное деяние в течение 14 (четырнадцати) лет: пен - тюремное заключение, от 8 (восьми) до 15 (пятнадцати) лет» (HARMS, 2016, стр. 577).

Кроме того, 6 ноября 2017 года Высший суд правосудия (STJ) выпустил резюме 593, в котором решительно определяет, что оно не имеет отношения к характеристике преступления согласия или нет жертвы:

O crime de estupro de vulnerável se configura com a conjunção carnal ou prática de ato libidinoso com menor de 14 anos, sendo irrelevante eventual consentimento da vítima para a prática do ato, sua experiência sexual anterior ou existência de relacionamento amoroso com o agente. (Súmula 593, TERCEIRA SEÇÃO, julgado em 25/10/2017, DJe 06/11/2017) (BRASIL, 2017).

Таким образом, бразильское законодательство еще более четко определяет, что независимо от обстоятельств принятия или непринятия ребенка или подростка, фракторы, упомянутые в отношении сексуального надругательства, применяются и квалируются как преступления.

Кроме того, тот фракт, что жертва каким-то образом соглашается, может вызвать усиление чувства вины и усугубить эмоциональный ущерб, помимо подтверждения его молчания о пережитом насилии и, во многих случаях, благоприятствования ребенку или подростку продолжать подвергаться сексуальному насилию. Для Padilha (2002) продолжительность злоупотребления может состоять из изолированного или рутинного эпизода продолжительностью в несколько лет без раскрытия третьим лицам. Агрессия может быть совершена с жертвами любого возраста, от младенцев или очень маленьких детей, до подросткового возраста.

Кроме того, гипотезы о поведении сговора с таким насилием устанавливаются по поведению матери, отца или отчима, или ребенка, исходя из истории жизни, которые иногда повторяют закономерности прошлых поколений. Отсутствие репертуара самозащиты может быть связано с неадекватными моделями родителей, у которых, возможно, не было адекватной модели своих родителей,

RC: 98980

Доступно в: https://www.nucleodoconhecimento.com.br/психология/историческиеаспекты 
и так далее. «Этот механизм повторения между годами рискованного поведения объясняет, почему матери, отцы или отчимы становятся «слепыми» в отношении сексуального насилия [...]» (PADILHA, 2002, стр. 211). То есть они не могут идентифицировать доказательства насилия.

Кроме того, стадия развития, на которой находится жертва, имеет вмешательство как в процесс обнаружения, так и в суд над подозреваемым: «Жестокое обращение с детьми является преступлением, которое часто может быть доказано только показаниями детей дошкольного возраста. Если показания ребенка неверны, невинный взрослый может быть несправедливо наказан» (PAPALIA; OLDS; FELDMAN, 2006, с. 301). Как справедливо отмечают авторы, маленький ребенок может в конечном итоге «вспомнить» события, которые не произошли; они, как правило, наводят на размышления, и их речь может быть вызвана другим человеком, и трудно различить ложь речи ребенка, который опрашивается кем-то, кто задает вопросы с предвзятыми деталями. Это может произойти в основном с детьми в возрасте до четырех лет, потому что на этом этапе дети чаще совершают ошибки в запоминание деталей события, которое меняется с повторением. Тем не менее, Habigzang, Ramos и Ekoller (2011) ссылаются на момент раскрытия сексуального насилия как на решающий в жизни жертвы, поскольку он может вызвать повторную виктимизацию, если взрослые не поверят в речь ребенка и не примут соответствующих защитных мер, которые должны иметь аффрективная и социальная сеть поддержки, которая состоит из систем или людей, значимых для жертвы.

Nos casos de abuso sexual contra crianças e adolescentes compreende-se como constituinte da rede: família, escola, comunidade, Conselho Tutelar, Delegacia, Conselho de Direitos da Criança, Ministério Público e Juizado da Infância e Adolescência, abrigos, serviços de saúde (postos de saúde e hospitais) e assistência social (Centro de Referência da Assistência Social e Centro de Referência Especializado da Assistência Social) (HABIGZANG; RAMOS; KOLLER, 2011, p. 468).

RC: 98980

Доступно в: https://www.nucleodoconhecimento.com.br/психология/исторические- 
Таким образом, все эти учреждения несут ответственность за защиту жертвы, стремясь планировать и осуществлять мероприятия, которые эфрфективно сводят к минимуму последствия насилия, от которого страдают дети или подростки (HABIGZANG; RAMOS; KOLLER, 2011). Школа выделяется тем, что это среда, присутствующая на очень важных этапах жизни детей и подростков в ее развитии.

Bce еще уточняя последствия в развитии жертвы сексуального насилия, Papalia; Olds и Feldman (2006) показывают наиболее распространенные цитаты по возрасту: в дошкольном возрасте выделяются тревога, ночные кошмары и неадекватное сексуальное поведение; у детей школьного возраста наблюдается агрессивное поведение, школьные проблемы, страх, гиперактивность и даже психические заболевания; наконец, подростки обычно имеют депрессию, фризические жалобы, бегство, незаконные действия, саморазрушительное или суицидальное поведение и злоупотребление психоактивными веществами.

Santos; Costa и Granjeiro (2009) отмечают, что большинство случаев сексуального надругательства происходит в семье, $и$ наиболее распространенные случаи сексуального надругательства практикуются биологическими родителями жертв и, во-вторых, отчимами. Это тип внутрисемейного насилия, который, согласно Araújo (2002), происходит в семье с участием людей, которые проживают или не проживают в одном и том же месте, но это не ограничивается только семьей, но затрагивает субъектов общего уюта в одном домашнем пространстве, независимо от того, имеют ли они родственные связи или нет. Таким образом, можно утверждать, что существует риск того, что люди будут идеализировать определенный стереотип для таких насильников, не платя за то, чтобы, даже если они являются работниками, «семейными родителями», налогоплательщиками, имеют хорошую социальную жизнь, являются богатыми, добрыми и образованными людьми или которые, по-видимому, воспитывают и хорошо заботятся о своих

RC: 98980

Доступно в: https://www.nucleodoconhecimento.com.br/психология/историческиеаспекты 
детях, это не означает, что такие люди не могут совершать сексуальное насилие, даже если они имеют похвальное поведение по отношению к обществу.

«Большинство педофилов не имеют судимости, и люди в своей жизни описывают их как работника, религиозного и ревностного опекуна своей семьи» (COHEN; MANNARINO, 2000a; Apud HABIGZANG et al, 2005, c.346).

Кроме того, агрессоры со стереотипами, рассматриваемыми в социальном отношении как добропорядохие граждане, могут спровоцировать приспособление людей не заботиться о профрилактике с детьми и подростками в отношении сексуального насилия, так как это также может сбить с толку в процессе подозрения и выявления этого насилия. Более того, в зависимости от отношений, которые агрессор имеет с семьей, о многих случаях не сообщается. Например, мать может не сообщать о своем супруге, потому что она доверяет ему, не отдавая должное жалобе ребенка или подростка, потому что она не хочет отдаляться от супруга или потому, что она зависит от агрессора, чтобы содержать семью, среди других ситуаций. Williams (2002) приводит еще один важный аспект, который заключается в том, что сексуальное насилие в настоящее время по-прежнему считается табу, и часто сама жертва стигматизируется и часто испытывает чувство вины или стыда; это, в частности, является одной из причин несообщения сообщений людьми, которые являются или не являются частью семьи жертвы.

Вместе с тем в работе Habigzang et al. (2005) представлено сопоставление фракторов риска внутрисемейного сексуального надругательства, которые были выявлены в ходе судебных процессов прокуратуры Риу-Гранди-ду-Сул ( Бразилия, проанализировав 71 файл, в которых представлен профиль агрессоров; одной из поразительных характеристик было то, что большинство агрессоров были безработными или с возможной работой. «Безработица является фрактором риска внутрисемейного насилия, поскольку она может

RC: 98980

Доступно в: https://www.nucleodoconhecimento.com.br/психология/историческиеаспекты 
порождать стресс и конфликт среди членов семьи» (HABIGZANG et al., 2005, с. 345). Кроме того, лицо, осуществляющее уход, в конечном итоге несет ответственность за ребенка или подростка в течение большей части времени, что предоставляет больше возможностей для возникновения сексуального насилия. Другими характеристиками, обнаруженными у большинства злоупотребляющих этим исследованием, являются: низкий уровень образования, женатые или живущие в браке, потребители алкоголя или наркотиков, среди прочего. Важно отметить, что эти характеристики были обнаружены в процентах изученных случаев и, хотя они довольно распространены, есть много насильников, которые не имеют ни одной из этих характеристик. Таким образом, важно, чтобы взрослые были внимательны и искали информацию, которая расширяет их знания о предмете и, таким образом, могли создать сеть защиты детей и подростков, будучи в состоянии не только выявлять, но и предотвращать, предотвращать сексуальное насилие.

По Brino и Willians (2005), сексуальное насилие над детьми можно предотвратить с помощью действий, которые можно разделить на три уровня профиллактики. Первый уровень - это первичный уровень, который направлен на устранение или уменьшение социальных, экологических и культурных фракторов, способствующих актам агрессии. Таким образом, могут поощряться действия, направленные на подготовку специалистов и других людей, непосредственно связанных с ребенком, таких как учителя. Кроме того, можно поощрять действия среди групп риска, содействуя просвещению детей о рисках сексуального надругательства.

Santos и Ippolito (2009) утверждают, что половое воспитание является лучшим способом предотвращения, и что, несмотря на принадлежность к взрослому, ответственному за образование детей и подростков, ответственность за их защиту от сексуального насилия, программа непрерывного образования способна подготовить детей и подростков к защите от этого насилия.

RC: 98980

Доступно в: https://www.nucleodoconhecimento.com.br/психология/исторические- 
Другим средством профилактики, упомянутым авторами, является социальная интеграция ребенка, рассматриваемого как «иная» или отвергнутая группами. «После подчинения ребенка сексуальному насилию, подвергаемого дома или по соседству, или его молчания перед ним обычно происходит поиск принятия и привязанности любимого человека» (SANTOS; IPPOLITO, 2009, с.128). Таким образом, многие из детей, ставших жертвами сексуального надругательства, имели низкий уровень самооценки и, как правило, росли в изоляции в своих собственных домах и в общине, в которой они живут, сочтя себя отличными от других и не имея фундаментальной сексуальной ориентации.

В целях профилактики Santos и Ippolito (2009 год) предлагают школам содействовать повышению осведомленности членов семьи, отвечающих за образование детей и подростков, используя творческий потенциал своих педагогов для работы с этими семьями, поощряя их и обучая их укреплению детей и подростков в борьбе с сексуальными надругательствами; поддерживать доверительные отношения с ребенком; посвящать этому время, и открыто прислушиваться к тому, что говорит ребенок, не тривиализируя в тех случаях, когда подвергшийся насилию ребенок «нарушает молчание», думая, что он, должно быть, выдумывает фракты и; создать сеть социальной поддержки среди членов семьи на работе, чтобы защитить ребенка в то время, когда член семьи, отвечающий за образование младшего, должен покинуть дом. Авторы заявляют, что: «Большинство актов внутри- и внесемейного надругательства имеют место, когда ребенок находится наедине с молодыми людьми и взрослыми в своем собственном доме или в доме знакомых» (SANTOS; IPPOLITO, 2009, c.129).

Второй подход, согласно Brino и Willians (2005), является вторичным, который направлен на раннее выявление детей, подверженных риску, тем самым предотвращая повторение актов насилия, работая над уменьшением стресса, вызванного процессом в правовой системе, через который проходит ребенок, учитывая, что поза специалистов, работающих с ребенком, может смягчить или

RC: 98980

Доступно в: https://www.nucleodoconhecimento.com.br/психология/историческиеаспекты 
в конечном итоге нанести психологический ущерб жертве. Третьим и последним подходом, представленным авторами, является третичный; он направлен на наблюдение за жертвой, а также агрессором с помощью подготовленных специалистов в целях предотвращения или смягчения потерь, вызванных сексуальным насилием, а также возможных долгосрочных последствий.

Учитывая важность работы по предотвращению сексуальных надругательств, действуя совместно с ответственными лицами и/или с ребенком, можно планировать мероприятия, направленные на первичную и вторичную профилактику. Матери, например, могут играть решающую роль в защите от этого насилия. «Когда они не в состоянии признать случаи сексуального насилия и защиты, ребенок может стать более уязвимым для жестокого обращения» (BRINO; WILLIANS, 2005, с.176). Поэтому важно изыскивать способы информирования матерей о сексуальном насилии, с тем чтобы они могли защитить ребенка от возникновения этого вида агрессии, и школа может быть стратегическим местом для таких действий, поскольку она является учреждением, способным содействовать вмешательствам с использованием прямого контакта с родителями, дети и подростки.

Brino и Willians (2005) подкрепляют идею о том, что расширение прав и возможностей детей и матерей распознавать признаки сексуального насилия может быть действием, которое эффективно останавливает возникновение указанного насилия. Это вмешательство, направленное на ребенка, будет включать распознавание признаков приближения к агрессору, а также признание неуместного сексуального поведения. Для матерей это действие будет включать в себя распознавание поведения, которое является показателем успешного насилия. Когда предложение о действиях заключается в выявлении детей и подростков, подверженных риску, нарушении насильственных действий или их повторении, вмешательство в уже подтвержденных случаях и работу по предотвращению возможных

RC: 98980

Доступно в: https://www.nucleodoconhecimento.com.br/психология/историческиеаспекты 
последствий, эта перспектива подходит для вторичной или даже третичной профилактики.

В дополнение к профилактике принципиально важно, чтобы мы знали, что делать, если сексуальное насилие уже имело место. Необходимо знать, как осуждать, заботиться о жертве, оказывая необходимую поддержку и обращаясь к специализированным методам лечения (BRINO; WILLIAMS, 2003b, стр.2).

Один из способов представления докладов, как показано на веб-сайте UNICEF[7], заключается в том, чтобы связаться с Советом по опеке, считая, что за обеспечение прав детей и подростков отвечают консультанты. При получении уведомления именно эти специалисты должны проанализировать происхождение каждого случая, совершая визиты к семье. Если это подтверждается, Совет передает ситуацию в прокуратуру.

Еще одним средством денонсации, на который указал UNICEF, является обращение в суды по делам детей и юности в случае муниципалитетов, в которых нет Совета по опеке. Жалобы могут также податься в полицейские участки по защите детей и подростков и женские полицейские участки. Существует также приложение для смартфонов и планшетов под названием Proteja Brasil, которое показывает телефоны и местоположение специализированного учреждения, ближайшего к тому, что есть у осведомителя. Кроме того, приложение предлагает помощь в случае сомнений относительно типа насилия.

Наберите 100 - Права человека - это канал, через который «жалобы могут быть анонимными или, по запросу заявителя, конфиденциальность источника инфрормации гарантируется» (BRASIL, s / d). Таким образом, любой может подать жалобу без идентификации. Сообщение не является синонимом обвинения, поскольку расследование фрактов будет проводить специализированный профессионал. Поэтому важно подчеркнуть, что нет

RC: 98980

Доступно в: https://www.nucleodoconhecimento.com.br/психология/историческиеаспекты 
необходимости быть уверенным в том, что сексуальное насилие имело место, чтобы сообщить о нем. Это акт приверженности безопасности и благополучию детей и подростков, а бездействие - акт столь же серьезный, как и само сексуальное насилие. ЕСА в единственном абзаце ст. 70-B, определяет, что

São igualmente responsáveis pela comunicação de que trata este artigo, as pessoas encarregadas, por razão de cargo, função, ofício, ministério, profissão ou ocupação, do cuidado, assistência ou guarda de crianças e adolescentes, punível, na forma deste Estatuto, o injustificado retardamento ou omissão, culposos ou dolosos (BRASIL, 1990).

Таким образом, в Статуте подчеркивается ответственность людей, которые так или иначе вовлечены в жизнь ребенка и подростка, чтобы подать жалобу в случае нарушения их прав. Это подтверждает обязательство разоблачать такое серьезное деяние, как сексуальное насилие, даже если это подозрение.

С учетом этих замечаний понимается, что сексуальное насилие является серьезной проблемой с широкой историей, которая пронизывает политические дискуссии, культурные ценности (которые меняются в зависимости от регионов мира и с историческим моментом), а также для фризических, психологических и социальных проблем здоровья, которые могут серьезно поставить под угрозу жизнь многих детей и подростков.

\section{3. ОКОНЧАТЕЛЬНЫЕ СООБРАЖЕНИЯ}

Цель этой статьи - рассмотреть исторические аспекты сексуального насилия, рассмотреть бразильское законодательство и исследовать сложности этого вопроса даже в отношении определения и номенклатуры.

Было замечено, что дети и подростки не всегда рассматривались как люди, нуждающиеся в особом уважении и заботе, и что на протяжении всей истории различные виды насилия совершались против этой общественности без

RC: 98980

Доступно в: https://www.nucleodoconhecimento.com.br/психология/исторические- 
наказания агрессоров, даже без внимания государственных властей для защиты этих людей.

Столкнувшись с рядом случаев жестокости и небрежности, были приняты законы в пользу детей и подростков, а в Бразилия ЕСА отмечает установление ряда прав, предусматривающих защиту несовершеннолетних и требующих от взрослых нести ответственность за уход за ними.

Таким образом, сексуальное надругательство является одним из явлений, привлекших внимание государства, и в настоящее время приняты меры по защите от такого насилия. Исследования показывают биопсихосоциальный ущерб, который эта агрессия может нанести жертве и ее семье, а также механизмы, связанные с практикой сексуального надругательства, позволяющие принимать стратегии профилактики и выявлять и наказывать агрессоров различного профиля.

Тем не менее известно, что население в целом по-прежнему не имеет знаний по этому вопросу, включая членов семьи и учреждения, которые отвечают за защиту детей и подростков, такие как, например, школа. Кроме того, отсутствие разъяснений В отношении этого явления является фрактором, подтверждающим, что это насилие продолжает воспроизводиться. Таким образом, существует необходимость в проведении дополнительных исследований и мероприятий, которые предоставляли бы населению все больше и больше информации по этому вопросу, повышая осведомленность об участии всех в обеспечении прав детей и подростков, тем самым усиливая борьбу с сексуальными надругательствами.

RC: 98980

Доступно в: https://www.nucleodoconhecimento.com.br/психология/историческиеаспекты 


\section{ИСПОЛЬЗОВАННАЯ ЛИТЕРАТУРА}

ADED et al. Abuso sexual em crianças e adolescentes: revisão de 100 anos de literatura. Revista de Psiquiatria Clínica 33 (4); 204-213, 2006. [online]. Disponível em: <http://www.hcnet.usp.br/ipq/revista/vol33/n4/204.html>. Acesso em: 27 de mai. de 2015.

ARAÚJO, M. de F. Violência e Abuso Sexual na Família. Psicologia em Estudo, Maringá, v. 7, n. 2, p. 3-11, jul./dez. 2002. [online]. Disponível em: $<$ http://www.scielo.br/scielo.php?pid=S1413-

$73722002000200002 \&$ script=sci_arttext>. Acesso em: 09 de set. de 2015.

AZAMBUJA, M. R. F. de. Violência sexual intrafamiliar: é possível proteger a criança? Revista Virtual Textos \& Contextos, nº 5, nov. 2006. [online]. Disponível em: <http://revistaseletronicas.pucrs.br/ojs/index.php/fass/article/view/1022>. Acesso em 09 de set. de 2015.

BRASIL. Ministério da Saúde. Notificação de maus-tratos contra crianças e adolescentes pelos profissionais de saúde. Secretaria de Assistência à Saúde. Série A. Normas e Manuais Técnicos; n. 167. Brasília-DF, 2002. [online]. Disponível em: <http://bvsms.saude.gov.br/bvs/publicacoes/notificacao_maustratos_criancas_adoles centes.pdf>. Acesso em: 27 de mai. de 2015.

Site: Conselho Nacional de Saúde. 18 de maio - Dia nacional de combate ao abuso e exploração sexual de crianças e adolescentes. s/d. Disponível em <http://conselho.saude.gov.br/ultimas_noticias/2009/15_mai_caesca.htm>. Acesso em: 06 de jun. de 2016.

Constituição (1988). Constituição da República Federativa do Brasil: promulgada em 5 de outubro de 1988. [online]. Disponível em: <http://www.planalto.gov.br/ccivil_03/Constituicao/Constituicao.htm>. Acesso em: 07 de out. de 2016.

RC: 98980

Доступно в: https://www.nucleodoconhecimento.com.br/психология/историческиеаспекты 
. Estatuto da Criança e Adolescente. Lei 8.069, de 13 de julho de 1990. Brasília, 1990. [online]. Disponível em: $<$ http://www.planalto.gov.br/ccivil_03/LEIS/L8069.htm>. Acesso em 09 de set. de 2015.

Superior Tribunal de Justiça. Súmula 593. O crime de estupro de vulnerável se configura com a conjunção carnal ou prática de ato libidinoso com menor de 14 anos, sendo irrelevante eventual consentimento da vítima para a prática do ato, sua experiência sexual anterior ou existência de relacionamento amoroso com o agente. Terceira Seção. Julgado em 25/10/2017. DJe 06/11/2017. Disponível em <https://www.stj.jus.br/sites/portalp/Inicio>. Acesso em: 14 de abr. de 2021.

BRINO, R. F.; WILLIAMS, L. C. Capacitação do educador acerca do abuso sexual infantile. Interação em Psicologia, 7(02), p. 1-10, 2003b. [online]. Disponível em:<file:///C:/Users/Usuario/Downloads/3218-6348-1-PB\%20(1).pdf>. Acesso em 13 de abr. de 2016.

. Prevenção primária, secundária e terciária do abuso sexual infantil. In:Sobre o comportamento e cognição- Expondo a variabilidade. Org. GUILHARDI, H. J.; AGUIRRE, N. C. de. p.174-181, 2005.

DECLARAÇÃO UNIVERSAL DOS DIREITOS HUMANOS, Adotada e proclamada pela resolução 217 A (III) da Assembléia Geral das Nações Unidas em 10 de dezembro de 1948. Representação da UNESCO no Brasil. Brasília, 1998. [online] Disponível em: <http://unesdoc.unesco.org/images/0013/001394/139423por.pdf>. Acesso em: 05 de jun. de 2016.

FALEIROS, E. T. S; CAMPOS, J. de O. C. Repensando os conceitos de violência, abuso e exploração sexual de crianças e de adolescentes. CECRIA / MJ-SEDH-DCA I FBB / UNICEF. Brasília, 2000. [online] Disponível em: $<$ http://escca.luizaugustopassos.com.br/wp-

RC: 98980

Доступно в: https://www.nucleodoconhecimento.com.br/психология/историческиеаспекты 
content/uploads/2011/02/livro_repensando_os_conceitos_eva_publicacoeshttpwww.mpes_gov_.branexoscentros_apoioarquivos1.pdf1.pdf>. Acesso em: 02 de jun. de 2016.

GUERRA, A. M. A. et al. Crianças e adolescentes têm direitos: conheça o Sistema de Garantia dos Direitos e saiba como participar. Org. GRACIANI, M. S. S. et al. $1^{\underline{a}}$ ed. São Paulo: CONDECA: Manufatura de ideias, 2013.

HABIGZANG, L. F. et al. Abuso sexual infantil e dinâmica familiar: aspectos observados em processos jurídicos. Psicologia: Teoria e Pesquisa, Brasília, v. 21, n.3, p.341-348, 2005.2 Disponível em:<http://www.scielo.br/scielo.php?script=sci_arttext\&pid=S0102$37722005000300011 \&$ Ing=en\&nrm=iso >. Acesso em: 07 de set. de 2016.

HABIGZANG, L. F.; RAMOS, M. da S.; KOLLER, S. H. A Revelação de Abuso Sexual: As Medidas Adotadas pela Rede de Apoio. Psicologia: Teoria e Pesquisa Out-Dez 2011, Vol. 27 n. 4, pp. 467-473. [online]. Disponível em: <http://www.scielo.br/pdf/ptp/v27n4/10.pdf >. Acesso em: 09 de set. de 2015.

HARMS, M. (org.) Vade Mecum RT. [Equipe RT]. 12 ed. revista, atualizada e ampliada. São Paulo: Editora Revista dos Tribunais, 2016. ISBN 978-85-203-6714-8.

INOUE, S. R. V.; RISTUM, M. Violência sexual: caracterização e análise de casos revelados na escola. Estudos de Psicologia (Campinas) [online]. 2008, vol.25, n.1, pp. 11-21. ISSN 1982-0275. Disponível em: $<$ http://www.scielo.br/scielo.php?pid=S0103166X2008000100002\&script=sci_abstract\&tIng=pt>. Acesso em: 27 de mai. de 2015.

LEMOS, F. C. S. O Estatuto da Criança e do Adolescente no Brasil atual. Revista Psicologia Política, São Paulo, v. 8, n. 15, p. 93-106, jun. 2008. Disponível em $<$ http://pepsic.bvsalud.org/scielo.php?script=sci_arttext\&pid=S1519549X2008000100007\&lng=pt\&nrm=iso >. Acesso em:08 de jun. de 2016.

RC: 98980

Доступно в: https://www.nucleodoconhecimento.com.br/психология/историческиеаспекты 
MINAYO, M. C. S. O significado social e para a saúde da violência contra crianças e adolescentes. In:WESTPHAL, M. F. (org). Violência e criança. São Paulo: Edusp, 2002.

OLIVEIRA, I. S. de. Trajetória Histórica do Abuso Sexual Contra Criança e Adolescente. UniCEUB: Brasília. 2006. Professor-orientador: Dr. Maurício Neubern.

PADILHA, M. da G. S. Abuso sexual contra crianças e adolescentes: considerações sobre os fatores antecedentes e sua importância na prevenção. In: GUILHARDI, H. J.; AGUIRRE, N. C. (Orgs.) Sobre Comportamento e Cognição: Expondo a variabilidade. Santo André: ESETec, 2002, v.10, p. 209 a 220.

PAPALIA, D.; OLDS, S.W.; FELDMAN, R. D. Desenvolvimento Humano. 8 ed.Porto Alegre: Artmed, 2006.

PRADO, M. do C. de A.; CARNEIRO, T. F. Abuso sexual e traumatismo psíquico. Interações, São Paulo, v. 10, n. 20, p. 11-34, dez. 2005. [online] Disponível em:<http://pepsic.bvsalud.org/scielo.php?script=sci_arttext\&pid=S1413$29072005000200002 \&$ Ing=pt\&nrm=iso $>$. Acesso em: 23 de abr. de 2016.

SANTOS. B. R. dos; IPPOLITO, R - Childhood Brasil. O papel da escola no enfrentamento da violência sexual. In: LAVARELLO, F. (Coord). A defesa de crianças e adolescentes vítimas de violências sexuais. São Paulo: Cromosete, 2009, p. $125-130$.

SANTOS, V. A. dos; COSTA, L. F.; GRANJEIRO, I. A. C. L. Intervenção no abuso sexual intrafamiliar: ingerência invasiva ou proteção devida? Psico, Porto Alegre, PUCRS, v. 40, n. 4, pp. 516-524, out./dez. 2009. [online]. Disponível em: <http://revistaseletronicas.pucrs.br/ojs/index.php/revistapsico/article/view/4009>. Acesso em: 09 de set. de 2015.

RC: 98980

Доступно в: https://www.nucleodoconhecimento.com.br/психология/историческиеаспекты 
SERAFIM, A. de P. et al. Dados demográficos, psicológicos e comportamentais de crianças e adolescentes vítimas de abuso sexual. Revista de Psiquiatria Clínica, São Paulo, v. 38, n. 4, p. 143-147, 2011. [online]. Disponível em: $<$ http://www.scielo.br/scielo.php?script=sci_arttext\&pid=S0101 60832011000400006>. Acesso em: 09 de set. de 2015.

UNICEF. Situação mundial da infância (edição especial): celebrando 20 anos da Convenção sobre os Direitos da Criança. UNICEF, 2009. [online] Disponível em: <http://www.unicef.org/brazil/pt/sowc_20anosCDC.pdf>. Acesso em: 03 de jun. de 2016.

VEGA, L. B. da S.; PALUDO, S. dos S. Exploração sexual e rede de proteção na perspectiva da vítima. Arquivos Brasileiros de Psicologia, Rio de Janeiro, v. 67, n. 2, p. 47-60, 2015.

Disponível em

<http://pepsic.bvsalud.org/scielo.php?script=sci_arttext\&pid=S1809$52672015000200005 \&$ lng=pt\&nrm=iso $>$. Acesso em: 29 de maio de 2016.

WAISELFISZ, J. J. Atendimento por Violência No SUS. In: Mapa da Violência 2012: Crianças e Adolescentes do Brasil. 1 ed. Rio de Janeiro: CEBELA, 2012. p.62-73.

WILLIAMS, L. C. A. Abuso sexual infantil. In: GUILHARDI, H. J.; AGUIRRE, N. C. (Orgs.). Sobre Comportamento e Cognição: Expondo a variabilidade. Santo André: ESETec, 2002, v.10, p.155-164.

\section{ПРИЛОЖЕНИЕ - СПРАВОЧНАЯ СНОСКА}

3. Данные, полученные в https://agenciapatriciagalvao.org.br/violencia/violenciasexual/tres-criancas-ou-adolescentes-sao-abusadas-sexualmente-no-brasil-a-cadahora/

4. Веб-сайт портала Бразилии: < http://www.brasil.gov.br/cidadania-ejustica/2015/07/em-1927-o-brasil-ganhou-oprimeiro-codigo-de-menores> .

RC: 98980

Доступно в: https://www.nucleodoconhecimento.com.br/психология/историческиеаспекты 
5. Сайт ВДПЧ: < http://www.dudh.org.br/declaracao/> .

6. Сайт CRAMI: <http://www.cramicampinas.org.br

7.

Веб-сайт

UNICEF:

<http:

www.unicef.org/brazil/pt/activities_10790.htm="'">.</http:>

Представлено: Май, 2021.

Утвержден: Сентябрь 2021 года.

RC: 98980

Доступно в: https://www.nucleodoconhecimento.com.br/психология/историческиеаспекты 